ISSN 1991-8631

Original Paper

http://indexmedicus.afro.who.int

\title{
Potential for agronomical enhancement of millet yield via Jatropha curcas oilcake fertilizer amendment using placed application technique
}

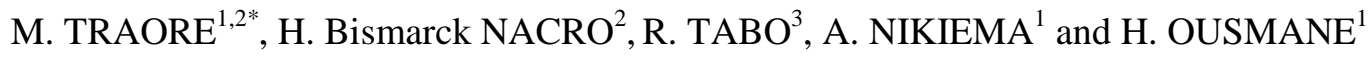 \\ ${ }^{1}$ International Crops Research Institute for Semi Arid Tropics (ICRISAT), P.O. Box: 12404, Niamey, Niger. \\ ${ }^{2}$ Université Polytechnique de Bobo, Institut du Développement Rural, \\ 01 BP. 1091 Bobo-Dioulasso 01 Burkina Faso. \\ ${ }^{3}$ Forum for Agricultural Research in Africa (FARA), 12 Anmeda Street, Roman Ridge, Accra, Ghana. \\ *Corresponding author, E-mail: iribatraore@yahoo.com
}

\begin{abstract}
This study carried out at the ICRISAT research station of Sadore in Niger aimed at determining the impact of placed application technique of Jatropha oilcake on millet agronomic parameters. The experimental design was a randomised blocs including five treatments and four replicates. Control was plots without fertilizer while J_100 g, J_200 g, and J_300 g were plots receiving $100 \mathrm{~g}, 200 \mathrm{~g}$ and $300 \mathrm{~g}$ of Jatropha oilcake respectively per seed hole and the plots NPK_6 g were receiving $6 \mathrm{~g}$ of NPK $(15,15,15)$ per seed hole. ANOVA test was used for data analyses. Only the Control had significantly low number of tillers. At the end of the vegetative period J_300 g has the highest plants. J_300 g induced 196\% increase of grain yield compared to the Control. The substitution of NPK $(15,15,15)$ by $100 \mathrm{~g}, 200 \mathrm{~g}$ and $300 \mathrm{~g}$ of Jatropha oilcake per seed hole induced $79-52.93 \%, 92-72.23 \%$ and $152-100.65 \%$ increase of grain yield respectively compared to the Control in 2009 and 2010. With regard to the grain yield in 2009 and 2010, $100 \mathrm{~g}$ of Jatropha cake per seed hole can replace the current $6 \mathrm{~g}$ (NPK) per seed hole.
\end{abstract}

(C) 2012 International Formulae Group. All rights reserved.

Keywords: Jatropha oilcake, NPK $(15,15,15)$, millet (H.K.P), placed application, fertilizer, Sadoré -Niger.

\section{INTRODUCTION}

Fertilizers use is one of the most constraining factors of millet production in Niger and thus a major cause of low millet yield. Inorganic or organic fertilizers have been used in research stations in Niger at the dose of $100 \mathrm{~kg}$ of NPK $(15,15,15)$, and 5 tons of organic manure per hectare to increase millet yield, but the recommended doses of fertilizers are often not affordable for subsistence farmers due to high quantity of the recommended doses and/or the physical availability of the fertilizer. Indeed, the majority of millet producers in Niger are resource poor farmers unable to buy mineral fertilizers, and crop residues for organic manure production is often used for animal feeding in extensive cattle breeding system or as firewood.

To address the constrain of fertilizer use and increase the productivity of millet in subsistence farming, various investigations have been conducted to develop effective techniques in order to increase fertilizer use efficiency, and reduce investment costs to resource poor farmers (Bationo et al., 1991a, 
b; Buerkert and Hiernaux, 1998). The fertilizer placement technique was therefore developed. It consists in applying small doses of fertilizer in the hill of the target grain crop at planting rather than broadcasting it all over the field. The amount applied is typically 60 to $80 \%$ of the recommended rates for maximum yield (Muehlig-versen et al., 2003; Tabo et al., 2004; Tabo et al. 2005; Tabo et al., 2008).

The fertilizer placement technique was successfully implemented across Africa with located application of $\mathrm{P}$ fertilizer in Malawi and in southern Nigeria on maize (Brown, 1966; Fox and Kang, 1978); in Western Niger on millet with NPK $(15,15,15)$ as fertilizer (Bationo et al., 1992; Davis et al., 1994; Muehlig-versen et al., 2003). In Burkina Faso, Ghana, and Niger, the application of $6 \mathrm{~g}$ NPK $(15,15,15) /$ seed hole on millet or maize led to 45 to $120 \%$ of yield increase and farm income increase of 50 to $130 \%$ compared to the broadcasting application of fertilizer all over the field (Tabo et al., 2008). All these success stories of fertilizer placement technique were implemented with mineral fertilizers but, very few investigations have been done on the potential of organic manure like compost and by-products. The choice of Jatropha oilcake as organic fertilizer is due to the fact that many countries have recently adopted new policies which call for an increase in bio fuel production (Jenkins, 2009; Eisentraut, 2010). Jatropha curcas seeds oil offers one of the best biodiesel without compromising food production in SubSaharan Africa since the oil is not edible and the tree can be associated with annual crops. Furthermore, seedcake generated from oil production is usable as organic manure. Several authors have reported its high nutrients content and positive impact on cereal yields (Heller, 1993; Gubitz et al., 1999).

The study reported herein aims to determine the impact of Jatropha oilcake on millet agronomic parameters: growth rate, grains, and biomass production and the efficient dose application of Jatropha oilcake on millet crop.

\section{MATERIALS AND METHODS Site conditions}

The experiment was conducted during the rainy seasons (June-October) of 2009 and 2010 at the research station of the International Crops Research for Semi Arid Tropics in Sadoré $\left(13^{\circ} 15^{\prime} \mathrm{W}, 2^{\circ} 18^{\prime} \mathrm{E}\right.$ coordinates; $240 \mathrm{~m}$ altitude) in Niger. Soil in the site was sandy in texture and classified as Luvic Arenosol or a Psammentic Paleustalf (West et al., 1984).

Sadoré has a Sahelian climate. April and May are the hottest months with maximum temperatures varying between 37 and $43{ }^{\circ} \mathrm{C}$, while the coldest period goes from December to January $\left(18-27^{\circ} \mathrm{C}\right)$. The mean annual rainfall for the past 10 years was 550 $\mathrm{mm}$. A major part of the rain is received during May-September with August as the pick. The monthly distribution and total rainfall in 2009 and 2010 are summarized in Table 1.

\section{On farm operations:}

Pearl millet (Var. H.K.P) was used as vegetal material. Seedbed preparation consisted in superficial tillage ( $<10 \mathrm{~cm}$ depth) using a traditional tool "hiller". The seedling density was 10,000 plants/hectare. Different doses of Jatropha oilcake and NPK (15, 15, 15) were applied during seedling operation according to the placed application technique as documented (Tabo et al., 2004; Tabo et al., 2005); they took place in July $8^{\text {th }}, 2009$ and June $4^{\text {th }}, 2010$ after rainfalls of $45 \mathrm{~mm}$ and 26 $\mathrm{mm}$ respectively.

\section{Experimental design}

The experimental design included five (5) treatments ranged in completely randomized blocks with four (4) replicates. Each elementary plot had $104 \mathrm{~m}^{2}(13 \mathrm{~m} * 8$ $\mathrm{m})$. The treatments included: Control corresponding to no fertilizer; NPK $(15,15,15)$ _6 g and J_100 g, J_200 g , and J_300 g corresponding to Jatropha oilcake application at the dose of $100 \mathrm{~g}, 200 \mathrm{~g}$ and $300 \mathrm{~g}$ respectively per seed hole. The NPK contained in the Jatropha oilcake was: N 2.82 g.kg ${ }^{1}$; P 0.77 g.kg ${ }^{-1}$ and K 1.82 g. $\mathrm{kg}^{-1}$. 
Impact on soil basic parameters $(\mathrm{N}, \mathrm{P}, \mathrm{K}$, CEC, pH, organic carbon)

Impact of the treatments on soil basic parameters were determined in composite soil samples collected at the depths of $0-5 \mathrm{~cm} ; 5$ $-10 \mathrm{~cm}$ and $10-40 \mathrm{~cm}$ before and after conducting the trials according to (Bremner and Mulvaney, 1982; Olsen and Sommers, 1982; Knudsen and Paterson., 1982; Rhoades, 1982; McLean, 1982; Nelson and Sommers, 1982).

\section{Impact on millet agronomic parameters}

From the $6^{\text {th }}$ week after seedling (WAS) to fructification state, the agronomic parameters (millet high and the number of tillers) were measured every week. For this purpose, plants from 8 seed holes per plot were randomly selected and labelled among the 24 plants of 3 central seeding lines of each elementary plot. Plant height was measured from the button to the bud using tape ruler and the number of tillers counted manually. The growth rate was calculated using the formula [1]. Biomass and grain yield were determined on dry materials after harvest.

[1]. $\Delta \mathrm{h}(\%)=\left[\left(\mathrm{h}_{(\mathrm{n}+1)}-\mathrm{h}_{\mathrm{n}}\right) * 100 / \mathrm{h}_{\mathrm{n}}\right] ; \mathrm{n}=$ order of week.

\section{Determination of the effective dose of Jatropha oilcake}

The determination of the optimum dose of Jatropha oilcake was done using the following formula [2]:[2] $R=\frac{Y_{J}-Y_{\text {control }}}{D \alpha} ; \mathrm{Y}_{\mathrm{J}}=$ Grain yield the plots amended with different dose of Jatropha oilcake; $\mathrm{Y}_{\text {control }}=$ Grain yield on the control; $\mathrm{D} \alpha=$ Dose of Jatropha oilcake.

\section{Statistical analysis}

Statistical analysis of data was carried out using standard analysis of variance (Gomez and Gomez, 1984). The significance of the treatment effect was determined using the ANOVA test and to determine the significance of the difference between the means of the two treatments, least significant differences (lsd) were estimated at the 5\% probability level (Ghosh et al., 2004). The
Student-Newman-Keuls test was used for multiple comparison and sorting the means of biomass production and grain yield.

\section{RESULTS}

Impact of treatments on soil parameters

Soil organic carbon (SOC), $\mathrm{pH}$ and nutrients balance before and after NPK and Jatropha oilcake treatments are summarized in Table 2. The basic soil parameters before any treatment show low fertility status of the investigated soil. As shown, by $\mathrm{pH}$ and nutrients balance after two years of investigation, any of the treatments did not affect significantly the soil basic parameters (Table 2). However, accumulation in total $\mathrm{N}$ content of soil and positive variation of $\mathrm{pH}$ indifferently to treatments were recorded.

\section{Impact of treatments on millet agronomic parameters}

Millet agronomic parameters were evaluated using the growth rate; numbers of tillers and ears; biomass and grain yield production.

\section{Millet growth rate affected by treatments}

Figures $1 \mathrm{a}$ and $1 \mathrm{~b}$ summarize millet growth rate according to the vegetative periods in 2009 and 2010 respectively.

In 2009, only treatment with NPK_6 g had significantly high millet growth rate compared to the other treatments $6^{\text {th }}$ to $7^{\text {th }}$ weeks after seedling (WAS).

Data recorded in 2009 showed significant increase of mean millet height over the vegetative period [p (Date) $<.001]$. Indeed, the global growth trend was above (1.s.d $=15.8$ $\mathrm{cm}$ ) indifferently to the treatments (Figure 1a). Beside the general trend, the growth rate on plots receiving fertilizer was higher than the one of the Control plots. Between $9^{\text {th }}$ WAS and $10^{\text {th }}$ WAS, the growth rate in the NPK_6 $\mathrm{g}$ plots decreased steadily and became significantly lower than the one of the Control plots due to the fast fructification of millet in the NPK_6 g plots. Field observation on the fructification rate showed that at $8^{\text {th }}$ WAS, $33 \%$ of the plants in the NPK_6 $g$ had ears while the others were at the fructification stage. 
In 2010, data collection started earlier, the same trend was observed but, after the stage of maximum growth; the decrease came one week later $\left(9^{\text {th }}\right.$ WAS $)$. The plots fertilized with Jatropha oilcake had lower growth rate than the ones of NPK from the $6^{\text {th }}$ WAS to the $8^{\text {th }}$ WAS (Figure1b). Comparing J_100 g, J_200 g and J_300 g, the increasing rate of application of Jatropha (100 g to $300 \mathrm{~g}$ per seed hole) did not lead to significant difference in the growth rate (Figure 1a and b) in 2009. In 2010, growth rate in J_100 g was significantly low compared to J_200 g and J_300 $\mathrm{g}$ whereas the same trend was observed as in 2009 for the growth rate in J_200 g and J_300 g.

\section{Number of tillers and ears}

In 2009 and 2010, the number of tillers with ears in the Control plots remained significantly low compared to the other treatments. J_300 $\mathrm{g}$ had the highest number of tillers followed by J_200 g. The number of tillers in J_100 g did not vary significantly from the ones of NPK_6 g (Figure 2).

Biomass production and grain yield

Table 3 showed the mean biomass and grain produced in the different treatments in 2009 and 2010; the global trend showed higher biomass and grain production in the fertilized plots compared to the plots with no fertilizer.

In 2009, only the placed application of NPK $(15,15,15)$ resulted in significant variation of the mean biomass production. Even if the placed application of Jatropha cake had positive effects on biomass production, the variations recorded in the plots J_200 g, J_100 g, and J_300 g were not significant compared to the control plots. However, biomass production was positively affected by Jatropha cake application in 2010 $(\mathrm{p}=0.004)$. Indeed, the plots receiving Jatropha oilcake had significantly high biomass production compared to the control plots (Table 3). Comparison between plots receiving different doses of Jatropha cake showed that J_300 $\mathrm{g}$ has the significantly highest biomass production while no significant variations were noticed between J_200 g and J_100 g.
Grain yields were significantly affected by the application of Jatropha cake in 2009 and $2010(\mathrm{p}<0.001$ and $\mathrm{p}=0.012)$ respectively.

In 2009, variation of grain yield ranged from $1275.42 \mathrm{~kg} / \mathrm{ha}$ in $\left(\mathrm{J} \_200 \mathrm{~g}\right)$ to 1790.83 $\mathrm{kg} / \mathrm{ha}$ in (J_300 g). There is not significant difference with the variation of the dose of Jatropha oilcake. J_300 g had significantly high grain yield compared to J_100 g and J_200 g (Table 3).

In 2010, no significant variation in biomass production was recorded between the Control plots and NPK_6 g even if NPK_6 g seamed to have higher biomass production. The plots receiving Jatropha oilcake as fertilizer had significantly the highest biomass compared to the Control plots and the ones fertilized with NPK $(15,15,15)$. There was no significant difference between J_200 g and $\mathrm{J} \_100 \mathrm{~g}$ but, biomass production in J_300 g was significantly higher than the one of J_200 g and J_100 g (Table 3).

Concerning grain yield, the fertilisation resulted in significant variation of the grain yield. NPK_6 $\mathrm{g}$ had the lowest grain yield among the fertilized plots followed by J_100 g. The placed application of $200 \mathrm{~g}$ and $300 \mathrm{~g}$ of Jatropha cake resulted into significant increase of grain yield when compared to the treatments NPK_6 g and J_100 g. However, there was no difference between J_200 g and $\mathrm{J} \_300 \mathrm{~g}$ even if the biomass produced in J_300 g seamed to be higher.

\section{Responses of millet biomass production and grain yield to the application of various doses of Jatropha oilcake}

Table 4 shows that the efficiency of Jatropha oilcake decreased significantly with the increasing rate of the application $p=0.006$ and $\mathrm{p}<0.001$ when considering the grain and biomass yield respectively in 2009. The same trend was observed in 2010 for grain yield ( $p$ $=0.001$ ) while biomass production did not vary significantly with the three different doses of Jatropha oilcake ( $p=0.056)$. 
M. TRAORE et al. / Int. J. Biol. Chem. Sci. 6(2): 808-819, 2012

Table 1: Monthly rainfall in 2009 - 2010 at Sadoré.

\begin{tabular}{lccccccccccccc}
\hline $\begin{array}{l}\text { Month } \\
\text { Year }\end{array}$ & Jan & Feb & Mar & Apr & May & June & July & Aug & Sept & Oct & Nov & Dec & Total \\
\hline 2009 & 0.0 & 0.0 & 0.0 & 2.7 & 19.3 & 60.4 & 142.0 & 202.2 & 67.2 & 21.8 & 0.0 & 0.0 & 515.6 \\
2010 & 0.0 & 0.0 & 0.0 & 1.2 & 24.9 & 83.7 & 149.2 & 187.3 & 143.0 & 98.2 & 0.0 & 0.0 & 687.3 \\
\hline
\end{tabular}

Table 2: Impact of treatments on soil parameters.

\begin{tabular}{|c|c|c|c|c|c|c|c|}
\hline \multirow{2}{*}{ Parameters } & \multirow{2}{*}{$\begin{array}{c}\text { Basic } \\
\text { parameters } \\
\text { before any } \\
\text { treatment }\end{array}$} & \multicolumn{5}{|c|}{ SOC and nutrients balance after treatments } & \multirow{2}{*}{$\begin{array}{c}\text { Significance of the } \\
\text { variation } \\
\text { p }\end{array}$} \\
\hline & & Control & NPK_6 g & J_100 g & J_200 g & $\mathbf{J} \_300 \mathrm{~g}$ & \\
\hline C. $\operatorname{Org}(\%)$ & $0.15 \pm_{0.01}$ & $0.00 \pm 0.00$ & $-0.02 \pm 0.01$ & $-0.02 \pm 0.04$ & $0.00 \pm 0.01$ & $0.01 \pm 0.02$ & 0.55 \\
\hline $\mathrm{pH}-\mathrm{H} 2 \mathrm{O}(1: 2.5)$ & $5.02 \pm 0.1$ & $0.33 \pm 0.14$ & $0.38 \pm 0.15$ & $0.48 \pm 0.02$ & $0.51 \pm 0.13$ & $0.5 \pm 0.09$ & - \\
\hline Total N (mg-N/Kg) & $13.5 \pm 9.45$ & $15.06 \pm 4.72$ & $6.11 \pm 5.28$ & $5.53 \pm 40.76$ & $5.13 \pm 34.25$ & $22.87 \pm 20.01$ & 0.29 \\
\hline Total-P(mgP/Kg) & $77.3 \pm 4.98$ & $-30.98 \pm 2.62$ & $-59.02 \pm 4.89$ & $-49.49 \pm 4.18$ & $-51.37 \pm 17.77$ & $\begin{array}{c}-47.62 \pm \\
15.21\end{array}$ & 0.18 \\
\hline Total-K(mgP/Kg) & $426.21 \pm 18.98$ & $-35.75 \pm 5.67$ & $-35.81 \pm 26.88$ & $-24.13 \pm 20.56$ & $-1.01 \pm 21.85$ & $\begin{array}{c}-59.82 \pm \\
22.43\end{array}$ & 0.53 \\
\hline Bray P1(mgP/Kg) & $5.79 \pm 1.9$ & $0.06 \pm 0.23$ & $-1.78 \pm 1.39$ & -2.60 & $-2.56 \pm 1.88$ & $-5.18 \pm 6.50$ & - \\
\hline $\mathrm{S}(\mathrm{cmol}+/ \mathrm{Kg})$ & $1.837 \pm 0.02$ & $-0.10 \pm 0.04$ & $-0.07 \pm 0.00$ & $-0.03 \pm 0.03$ & $0.06 \pm 0.03$ & $-0.08 \pm 0.04$ & - \\
\hline $\mathrm{CEC} \mathrm{Ag}(\mathrm{cmol}+/ \mathrm{Kg})$ & $0.79 \pm 0.14$ & $0.03 \pm 0.14$ & $0.05 \pm 0.11$ & $0.09 \pm 0.18$ & $-0.25 \pm 0.16$ & $-0.11 \pm 0.13$ & - \\
\hline
\end{tabular}


Table 3: Biomass and grain yield in 2009 and in 2010.

\begin{tabular}{|c|c|c|c|c|c|}
\hline & \multicolumn{2}{|l|}{2009} & \multirow{2}{*}{ Treatments } & \multicolumn{2}{|l|}{2010} \\
\hline & Mean Biomass (Kg/ha) & Mean Grain yield & & Biomass (kg/ha) & Grain (kg/ha) \\
\hline Control & $8489.58^{\mathrm{a}} \pm 3901.62$ & $710.06^{\mathrm{a}} \pm 50.88$ & Control & $9049.56^{\mathrm{a}} \pm 1817.19$ & $1227.98^{\mathrm{a}} \pm 83.26$ \\
\hline NPK_6 g & $18542.67^{\mathrm{b}} \pm 2322.89$ & $1978.46^{\mathrm{c}} \pm 295.25$ & NPK_6 g & $10627.71^{\mathrm{a}} \pm 2800.48$ & $1594.10^{\mathrm{ab}} \pm 160.75$ \\
\hline $\mathrm{J} \_100 \mathrm{~g}$ & $12677.08^{\mathrm{a}} \pm 1756.40$ & $1365.50^{\mathrm{b}} \pm 332.04$ & J_100 g & $16083.88^{\mathrm{ab}} \pm 5772.49$ & $1878.25^{\mathrm{ab}} \pm 620.86$ \\
\hline $\mathrm{J} \_200 \mathrm{~g}$ & $10125.00^{\mathrm{a}} \pm 2191.63$ & $1275.42^{\mathrm{b}} \pm 148.33$ & $\mathrm{~J} \_200 \mathrm{~g}$ & $19672.96^{\mathrm{ab}} \pm 7908.19$ & $2115.25^{\mathrm{b}} \pm 373.49$ \\
\hline $\mathrm{J} \_300 \mathrm{~g}$ & $13208.33^{\mathrm{a}} \pm 2495.83$ & $1790.83^{\mathrm{c}} \pm 306.68$ & $\mathrm{~J} \_300 \mathrm{~g}$ & $26165.17^{b} \pm 10304.59$ & $2463.83^{b} \pm 630.64$ \\
\hline
\end{tabular}

Table 4: Millet response to the variation of the application rate of Jatropha oilcake.

\begin{tabular}{llllll}
\hline 2009 & & & 2010 & & \\
\hline Treatments & Grain & Biomass & Treatments & Grain & Biomass \\
\hline J_300 g & $5.969^{\mathrm{a}}$ & $28.3^{\mathrm{a}}$ & J_300 g & $8.21^{\mathrm{a}}$ & $87.2^{\mathrm{a}}$ \\
J_200 g & $6.377^{\mathrm{a}}$ & $92.71^{\mathrm{b}}$ & J_200 g & $9.39^{\mathrm{a}}$ & $98.4 \mathrm{a}^{\mathrm{a}}$ \\
J_100 g & $13.655^{\mathrm{b}}$ & $132.08^{\mathrm{c}}$ & J_100 g & $21.15^{\mathrm{b}}$ & $160.8^{\mathrm{b}}$ \\
\hline
\end{tabular}




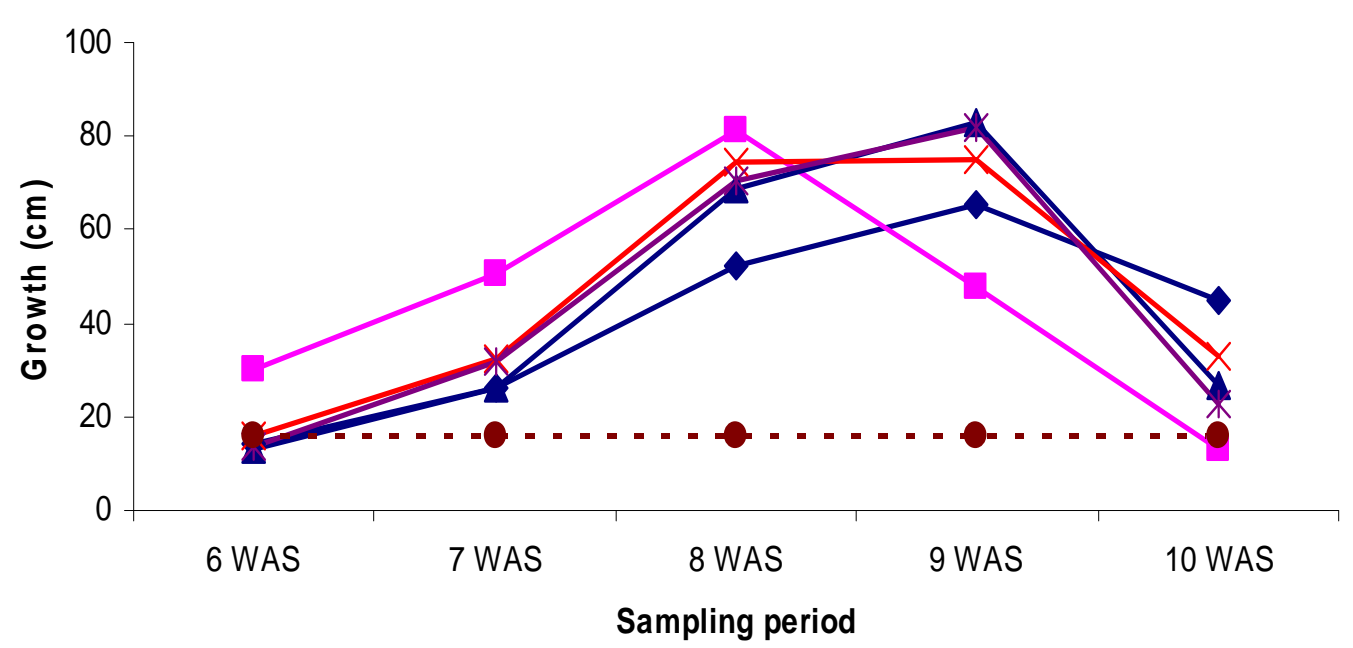

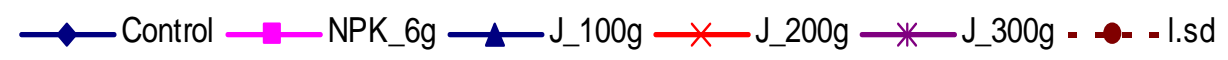

Figure 1a: Mean growth rate of Millet $(\mathrm{cm})$ over the vegetative period in 2009.

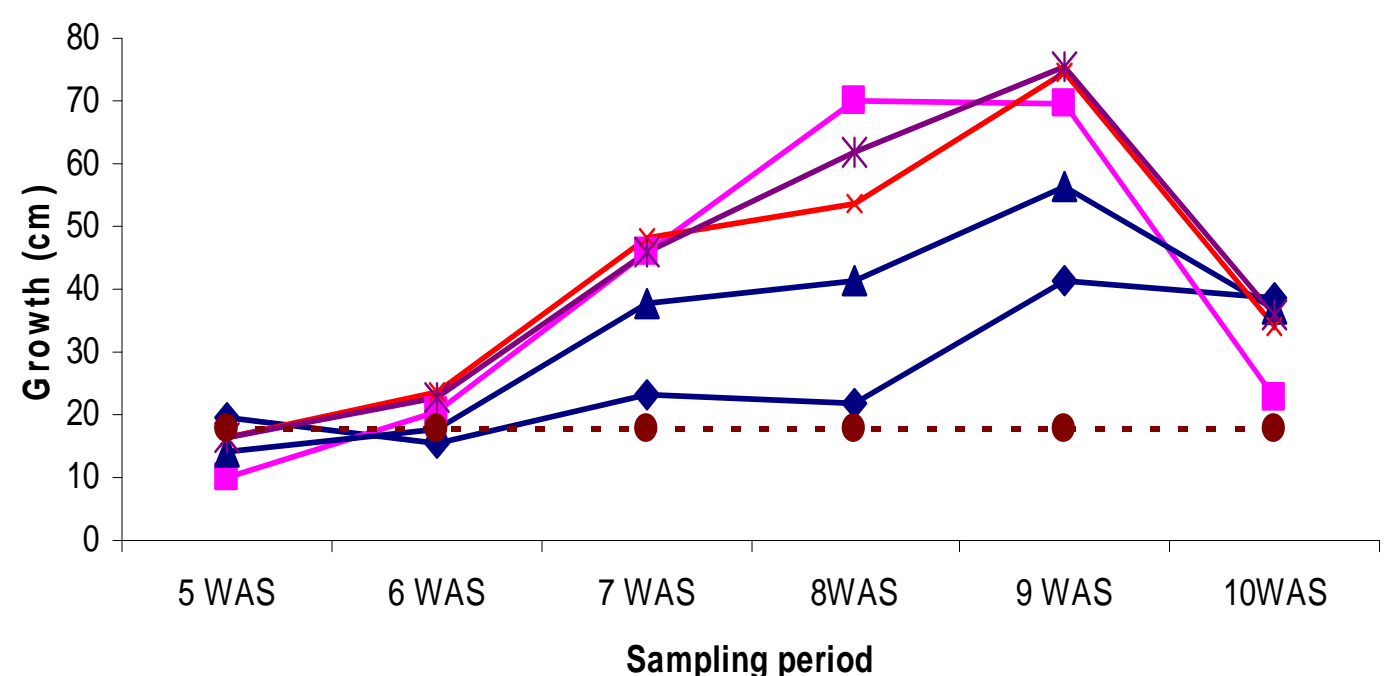

$\sim$ Control $\longrightarrow$ NPK_6g $\longrightarrow$ J_100g $\longrightarrow$ J_200g $\rightarrow$ J J_300g - ๑- - I.s.d

Figure 1b: Mean growth rate of Millet $(\mathrm{cm})$ over the vegetative period in 2010 . 


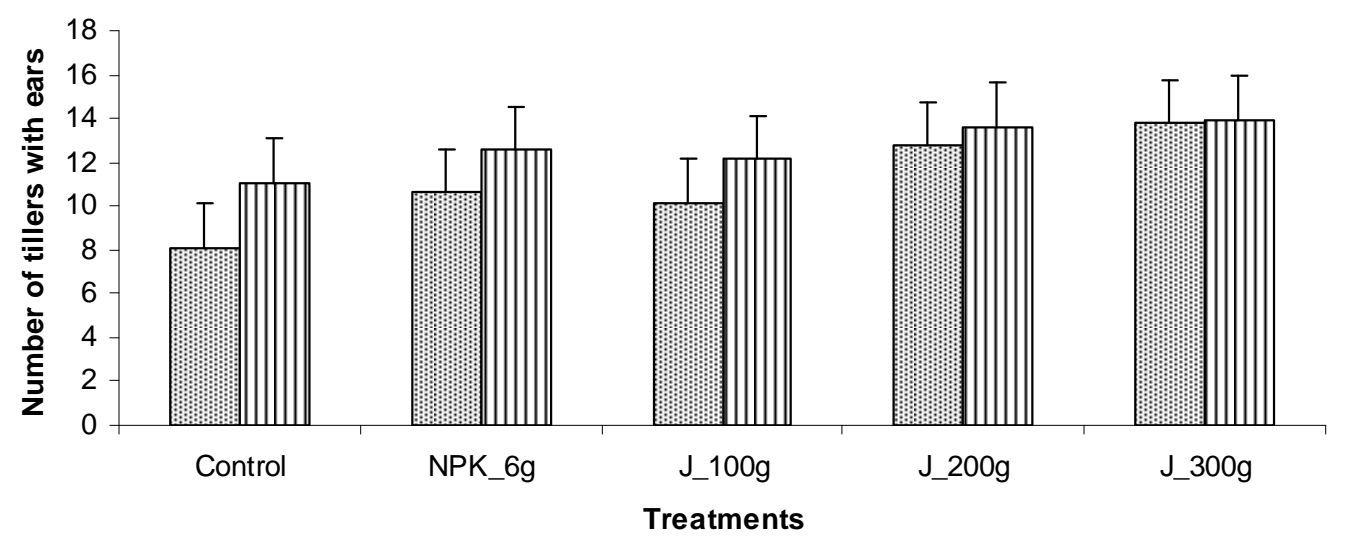

국 2009 2010

Figure 2: Mean number of tillers with ears per seedling hole in 2009 and 2010.

\section{DISCUSSION}

Application of manure or NPK $(15,15,15)$ fertilizer in nutrients depleted soils is essential for good expression of millet agronomic parameters. Jatropha oilcake does have potential as good organic manure for replacing chemical fertilizer since it has high nitrogen content (Staubmann et al., 1997; Gubitz et al., 1999; Kumar and Sharma, 2008). In the study reported herein, high growth rate, high number of tillers and ears recorded in the fertilized plots might be due to steadily release of major nutrients; nitrogen, phosphorus and potassium from Jatropha oilcake in J_100 g, J_200 g, and J_300 g or from NPK $(15,15$, $15)$ in NPK_6 g over the vegetative growth. Tabo et al. (2004), Tabo et al. (2008) have reported efficient expression of millet agronomic parameters with the application of $6 \mathrm{~g}$ of NPK $(15,15,15)$ per seedling hole. Millet agronomic performances (growth rate, number of tillers and number of ears) in plots amended with Jatropha oilcake were over the Control because of nutrients realised to the plants through the mineralisation of the Jatropha oilcake. In fact, analyses carried out on Jatropha oilcake used in the experiment showed that its content in major nutrients was: $2.82 \mathrm{~g} \cdot \mathrm{kg}^{-1} ; 0.77 \mathrm{~g} \cdot \mathrm{kg}^{-1}$ and $1.82 \mathrm{~g} \cdot \mathrm{kg}^{-1}$ for N, P and $\mathrm{K}$ respectively. Furthermore, despite the application of various doses of Jatropha oilcake, there was no significant accumulation of organic matter in the investigated soil after two consecutive production seasons $(\mathrm{p}=0.55)$. Also, the balance of the sol major nutrients, $\mathrm{P}$ and $\mathrm{K}$ were negative (Table 2) while irrelevant accumulation was observed for $\mathrm{N}(\mathrm{p}$ $=0.29$ ). Negative nutrients balance in soil under three groups of farmers rank according to fertility management was also reported by Assefa et al. (2007). The study portrayed that the severity of soil nutrients ( $\mathrm{N}, \mathrm{P}$ and $\mathrm{K}$ ) depletion increased from lower to higher application of fertilizer.

The low growth rate, biomass production and grain yield in the control is due to the fertility status of the experimental field. Although the trial was set in seven years fallow, soil basic parameters reported in Table 2 before setting the trial showed low fertility status (FAO, 1977; BUNASOLS, 1990). Earlier land survey has also reported native poverty and low nutrients storage capacity of the investigated soil (West et al., 1984). Low crops productivity of Sub Saharan sandy soils in general and in Sadoré as a consequence of nutrients deficiency have been also reported in previous investigations (Bonzi et al. 2008; Issaka et al 2008 ; Kihara et al., 2009 ; Bado et al., 2010).

In 2009, Jatropha oilcake was placed in direct contact with millet seeds in the seedling 
holes and it resulted in germination failure with direct impact on millet growth rate and stems vigour (Figure 1a). This could explain the lower growth rate of millet in Jatropha oilcake treatments relative to NPK treatment. In 2010, the trends were reversed (Figure 1b) because Jatropha oilcake was not placed in direct contact with millet seeds in the seedling hole. Earlier investigations carried out by Moreira (1970) showed that phytotoxicity reduces germination, when high rates up to 5 t/ha of Jatropha oilcake were applied as fertilizer. Even though the dose of the Jatropha oilcake was under $5 \mathrm{t} / \mathrm{ha}$ in our experiment, Jatropha oilcake was concentrated on the seeds in conformity with the placed application technique that could justify germination failure with direct consequences on biomass production.

Fast fructification of millet is important in sub Saharan conditions because of the erratic rainfall. In plots amended with Jatropha oilcake, the fructification of millet came a week later in 2009 and 2010 in comparison to the plots receiving NPK fertilizer. That is probably due to the kinetic of nutrients released from the oilcake to the soil solution. In fact, before being released for millet uptake, nutrients contained in Jatropha oilcake have to pass through the mineralization process while in NPK $(15,15,15)$ they are already under mineral form. Previous studies have also reported the kinetic of mineralization of organic manure as limitation factor for nutrients availability in amended soils (Thomas and Asakawa, 1993; Esse et al., 2001; Fatondji et al., 2009). In this study, the late ending of millet vegetative phase in plots fertilized with Jatropha oilcake had positive effects on millet dry matter production (Table 3) in 2010. Indeed, biomass production and grain yield were higher in plots receiving $100-300 \mathrm{~g}$ of Jatropha oilcake than the plots with NPK.

In 2009 biomass and grain yield in Jatropha oilcake treatments were lower than plots with NPK treatments because of the phytotoxicity effect outlined above. Concerning the Control plots, in addition to the late accomplishment of the vegetative cycle, biomass production and grain yield were significantly low in 2009 and 2010 and this is due to the poor fertility status of soil (Table 2). The overall data trend of biomass production and grain yield in 2009 and 2010 showed that millet response to fertilizer (NPK or Jatropha oilcake) was low in 2009. This may be due to the length of the vegetation period which lasted for 87 days and the quantity of rainfall $(515.6 \mathrm{~mm})$ while in 2010 , total rainfall was $687.3 \mathrm{~mm}$ and harvest came 128 days after seedling.

Biomass production and crop yield showed large variations among replications of experimental treatments (Table 3). These results are in agreement with (Ludger et al., 1994; Manu et al., 1996; Brouwer and Bouma, 1997) and it may be caused by differences in nutrient and/or moisture availability, as well as their interactions (Rockström et al., 1999).

The ratio indicating Jatropha oilcake efficiency decreased with the increase of the application rate of Jatropha oilcake (Table 4). Therefore nutrients contained in $100 \mathrm{~g}$ of Jatropha oilcake/ seedling hole seems to be sufficient for efficient expression of millet agronomic parameters. Over $100 \mathrm{~g}$ of Jatropha oilcake/seedling hole, the increase in dry matter production per unit weigh of Jatropha oilcake present less efficient in term of proportionality. The most economical dose for Jatropha oilcake amendment using the placed application technique is $100 \mathrm{~g}$ of Jatropha oilcake per seedling hole. Compared to NPK $(15,15,15)$, Jatropha oilcake offers more economical opportunities to resource poor farmers because it is an unusable by-product which can be utilized as alternative fertilizer.

\section{Conclusion}

Millet agronomic parameters (growth rate, number of tillers and number of ears) were positively affected by Jatropha oilcake fertilizer in 2010. However, grain yield and biomass production in plots fertilized with NPK $(15,15,15)$ were higher than those fertilized with Jatropha oilcake in 2009. Continuous application of Jatropha oilcake 
fertilizer in 2009 and 2010 showed better results when compared to the NPK. The increase of the of application rate of Jatropha oilcake from $100 \mathrm{~g}$ to $300 \mathrm{~g} / \mathrm{seed}$ hole improved biomass production and grain yield but, at the current step of our investigation, $100 \mathrm{~g}$ of Jatropha oilcake per seed hole can be recommended as substitute of $6 \mathrm{~g}$ of NPK (15, 15 , 15) per seedling hole in millet (HKP) production. With regard to the germination failure experienced in 2009, Jatropha oilcake should not be applied in direct contact to the seeds.

\section{ACKNOWLEDGEMENTS}

The authors are grateful to Hassan Ousmane and Ibrahim Maikano for their daily support during the field investigation; to ICRISAT Niamey and UPB/IDR- Bobo for the infrastructure and administrative facilities. We are highly indebted to the International START secretariat for their financial support for the implementation of this study through the African Climate Change Fellowship Program.

\section{REFERENCES}

Assefa A, Herman VK, Haile M, Simon JO. 2007. Nutrient dynamics on smallholder farms in Teghane, northern highlands of Ethiopia. In Advences in Integrated Soil Fertility Management in Sub-Saharan Africa: Challenges and Opportunities, Bationo A, Waswa B, Kihara J, Kimetu J (eds). Springer: The Netherlands, 365378.

Bado BV, Lompo F, Sedogo MP, Cescas MP. 2010. Establishment of the critical limit of soil-available phosphorous for maize production in low acidic ultisols of West Africa. Comm Soil Sci. Plant Anal., 41(8): 968-976.

Bationo A, Christianson CB, Baethgen WE, Mokwunye AU. 1992. A farm level evaluation of nitrogen and phosphorus fertilizer use and planting density for pearl millet in Niger. Fert. Res., 31: 175184.
Bationo A, Mokwunye AU. 1991a. Alleviating soil fertility constraints to increased crop production in West Africa: The experience in the Sahel. Fert. Res., 29: 95-115.

Bationo A, Mokwunye AU. 1991b. Role of manures and crop residues in alleviating soil fertility constraints to crop production: With special reference to the Sahelian and Sudanian zones of West Africa. Fert. Res., 29: 117-125.

Bonzi M, Lompo F, Sedogo MP. 2008. Promotion de l'Utilisation des Phosphates Locaux pour la Recapitalisation de la Fertilité des Sols au Sahel: Etat des Lieux des Connaissances sur la Valorisation Agronomique des Phosphates Naturels du Burkina Faso. Synthesis of Soil, Water and Nutrient Management Research in the Volta Basin, Bationo A, Tabo R, Waswa B, Okeyo J, Kihara J, Fosu M, Kaboré S (eds). Ecomedia Ltd: Nairobi, Kenya, 2005-232.

Bremner JM, Mulvaney CS. 1982. NitrogenTotal. In: Methods of Soil Analysis ( $2^{\text {nd }}$ edtn). Part 2: Chemical and Microbiological Properties. Page AL, Miller RH, Keeney DR (eds). American Society of Agronomy: Madison, Wisconsin; 595-624.

Brouwer J, Bouma J. 1997. Soil and crop growth variability in the Sahel: highlights of research (1990-1995) at ICRISAT Sahelian Centre. Information Bulletin 49. ICRISAT, Patancheru, Andrah Pradesh, India.

Brown P. 1966. Maize growing in Nyasaland (Malawi) II. Fertiliser requirements. Expl. Agric., 2(1): 49-60.

Buerkert A, Hiernaux P 1998. Nutrients in West African Sudano-Sahelian zone: losses, transfers and role of external inputs. J. Plant Nutr. Soil Sci., 161: 365383.

BUNASOLS. 1990. Manuel pour l'évaluation des terres. Documentation Technique 6, p. 181. 
Commission of the European Union. 2006. Report on the progress made in the use of biofuels and other renewable fuels in the Member States of the European Union. Biofuels Progress Report; Communication from the commission to the council and European parliament. COM (2006) 845 final, p. 16.

Davis JG, Manu A, Hossner L R, Persaud N. 1994. Phosphorus management of a millet/cowpea inter crop system on sandy dunal soils of Western Niger. J. Plant Nutr., 17(6): 899-910.

Eisentraut A. 2010. Sustainable production of second generation biofuels. Potential and perspectives in major economies and developing countries. Extended executive summary. information paper, International Energy Agency, Paris, p.16.

Esse PC, Buerkert A, Hiernaux P, Assa A. 2001. Decomposition of and nutrient release from ruminant manure on acid sandy soils in the Sahelian zone of Niger, West Africa. Agric Ecosyst Environ., 83(1-2): 55-63.

FAO. 1977. Directives pour la Description des Sols ( $2^{\mathrm{e}}$ edn). FAO: Rome; 72.

Fatondji D, Martius C, Zougmore R, Vlek PLG, Bielders CL, Koala S. 2009. Decomposition of amendment and nutrient release under the zaï technique in the Sahel. Nutr. Cycl. Agroecosyst., 85(3): 225-239.

Fox RL, Kang BT. 1978. Influence of phosphorus fertilizer placement and fertilization rate on maize nutrition. Soil Sci., 125(1): 34-40.

Ghosh PK, Ramesh P, Bandyopadhyay KK, Tripathi AK, Hati KM, Misra AK, Acharya CL. 2004. Comparative effectiveness of cattle manure, poultry manure, phosphocompost and fertilizerNPK on three cropping systems in vertisols of semi-arid tropics. I. Crop yields and system performance. $J$. Biortech., 95(1): 77-83.

Gomez KA, Gomez AA. 1984. Statistical Procedures for Agricultural Research.
John W, Sons I (2 eds). IRRI: New York; 30-207.

Gubitz GM, Mittelbach M, Trabi M. 1999. Exploitation of the tropical oil seed plant Jatropha curcas L. Bioresources Technol., 67(1): 73-82.

Heller J (1996). Physic nut. Jatropha curcas L. Promoting the Conservation and Use of Underutilized and Neglected Crops. Institute of Plant Genetics and Crop Plant Research (IPGRI), Gatersleben/ International Plant Genetic Resources Institute: Rome, Italy; 66.

Issaka R N, Buri M M, Tetteh F M, Boadi S. 2008: Review of work on Soil Phosphorus in Ghana. In Synthesis of Soil, Water and Nutrient Management Research in the Volta Basin, Bationo A, Tabo R, Waswa B, Okeyo J, Kihara J, Fosu M, Kabore S. (eds). Ecomedia Ltd; 189 - 2004.

Jenkins S. 2009. NRC: Cellulosic fuels to contribute strongly to energy portfolio. Ebibulletin Summer., 3(2): 1-8.

Kihara J, Vanlauwe B, Waswa B, Kimetu JM, Chianuand J, Bationo A. 2009. Phosphorus application in legume-cereal rotations increases land productivity and profitability in western kenya. Expl Agric., 46(1): 35-52.

Knudsen D, Paterson GA. 1982. Lithium, Sodium, and Potasium. In Methods of Soil Analysis ( $2^{\text {nd }}$ edn). Part 2: Chemical and Microbiological Properties. Page AL, Miller RH, D.R. Keeney (eds). American Society of Agronomy: Madison, Wisconsin; 225-247.

Kumar A, Sharma S. 2008. An evaluation of multipurpose oil seed crop for industrial uses: A Review. Indus Crops. Prod., 28(1): 1-10.

Ludger H, Hebel A, Stahr K. 1994. Influence of microvariability in sandy Sahelian soils on Millet growth. J. Plant Nutr. Soil Sci., 157: 111-115.

Manu, A, Pfordresher A.A, Geiger SC, Wilding LP, Hossner LR. 1996 Soil parameters related to crop growth 
variability in Western Niger, West Africa S.S.S.A.J., 60(1): 283-288.

McLean EO. 1982. Soil $\mathrm{pH}$ and lime Requirement. In Methods of Soil Analysis $\left(2^{\text {nd }}\right.$ edtn). Part 2: Chemical and Microbiological Properties. Page AL, Miller RH, D.R. Keeney (eds). American Society of Agronomy: Madison, Wisconsin; 199-209.

Moreira I. 1970. Bagaços de purgueira e de ricino. Ensaio sobre a sua fitotoxicidade e valor fertilizante. An. Inst. Super. Agron., 31: 191-222.

Muehlig-versen B, Buerkert A, Bationo A. 2003. Phosphorus placement on acid Arenosols of the west African Sahel. Expl Agric., 39: 307-325.

Nelson D W, Sommers LE. 1982. Total carbon, organic carbon and organic matter. In Methods of Soil Analysis ( $2^{\text {nd }}$ edtn). Part 2: Chemical and Microbiological Properties. Page AL, Miller RH, Keeney DR (eds). American Society of Agronomy: Madison, Wisconsin; 539-577.

Olsen S R, Sommers LE. 1982. Phosphorus. In Methods of Soil Analysis ( $2^{\text {nd }}$ edn). Part 2: Chemical and Microbiological Properties. Page AL, Miller RH, Keeney DR (eds). American Society of Agronomy: Madison, Wisconsin; 403427.

Rhoades J D. 1982. Cation exchange capacity. In Methods of Soil Analysis ( $2^{\text {nd }}$ edn). Part 2: Chemical and Microbiological Properties. Page AL, Miller RH, Keeney DR (eds). American Society of Agronomy: Madison, Wisconsin; 148157.

Rockström J, Barron J, Brouwer J, Galle S, de Rouw A. 1999. On-farm spatial and temporal variability of soil and water in pearl millet cultivation'. SSSAJ., 63: 1308-1319.
Staubmann R, Ncube I, Gubitz GM, Steiner W, Read JS.1999. Esterase and lipase activity in Jatropha curcas L. seeds. J. Biotechnol., 75: 117-126.

Tabo R, Bationo A, Hassane O, Amadou B, Fosu M, Kabore SS, Fatondji D, Ouattara K, Abdou A, Koala S. 2008. Fertilizer Microdosing for the Prosperity of Resource poor Farmers: a Success Story. Proceedings of the Workshop on Increasing the productivity and Sustainability of Rainfed Cropping Systems of Poor. Smallholder Farmers: Tamale, Ghana; 22-25.

Tabo R, Bationo A, Maimouna KD, Hassane O, Kouala S. 2005. Fertilisation par microdose pour la Prospérité du petit Paysan au Sahel : Rapport final. Niamey, Niger: International Crops Research Institute for the Semi - Arid Tropics, p. 24.

Tabo R, Konlambigue AM, Maatman A. 2004. Projet USAID TARGET sur 'Fertilisation par microdose pour la prospérité des petits producteurs au Sahel': Atelier de formation sur la technologie de transposition à grande échelle (scaling up) de la technologie de fertilisation par micro - dose. 20 - 24 Janvier 2004, Ouahigouya, Burkina Faso. B.P. 12404, Niamey, Niger. Institut International de Recherche sur les Cultures des Zones Tropicales Semi - Arides. p. 20.

Thomas RJ, Asakawa NM. 1993. Decomposition of leaf letter from tropical forage grasses and legumes. Soil Biol. Biochem., 25(10): 1351 - 1361.

West LT, Wilding LP, Landeck JK, Calhoun JG. 1984. Soil Survey of the International Crops Research Institute for the Semiarid Tropics Sahelian Center, Niger, West Africa. College Station: Texas: Soil and Crop Sciences Department/Tropical Soils, Texas A and M University System. 